\title{
Convergence of Interest Hypothesis: Examining the Impact of Managerial Ownership on Audit Quality of Quoted Manufacturing Companies in Nigeria
}

\author{
Ajayi-Owoeye Ayooluwa Olotu, Akinwunmi Abiodun Jelil, Adegbie Folajimi Festus
}

Department of Accounting, School of Management Sciences, Babcock University, Ilishan Remo, Nigeria

Email address:

ayooluwaolotu@yahoo.com (Ajayi-Owoeye A. O), akinabiodun@yahoo.com (Akinwunmi A. J), folaadegbie@yahoo.com (Adegbie F. F.)

\section{To cite this article:}

Ajayi-Owoeye Ayooluwa Olotu, Akinwunmi Abiodun Jelil, Adegbie Folajimi Festus. Convergence of Interest Hypothesis: Examining the Impact of Managerial Ownership on Audit Quality of Quoted Manufacturing Companies in Nigeria. Journal of Finance and Accounting. Vol. 8, No. 1, 2020, pp. 9-17. doi: 10.11648/j.jfa.20200801.12

Received: December 25, 2019; Accepted: January 10, 2020; Published: February 10, 2020

\begin{abstract}
The debate on the need for ownership of shares by management emanates as a result of the possible incongruence of objective that could happen among business executives and diverse shareholders when directors do not have shareholding stake in the companies they govern. Studies have shown that financial crisis reported across the global economy affect the credibility of financial information and confidence of stakeholders in quoted firms. This study examined the managerial ownership impact on audit quality of firms quoted on the Nigerian Stock Exchange from 2007 to 2017. The sample size was 36 manufacturing companies purposively selected from 185 firms listed on the NSE. The study used descriptive, correlational and experimental designs and multiple regressions for analysis. It was found that managerial ownership does not have a positive and significant impact on audit fees $(\beta=-0.241 ; \mathrm{p}=0.287)$ while managerial ownership structure has a negative but significant impact on audit size $(\beta=-0.562 ; \mathrm{p}$ - value $=0.002)$. The study concluded that managerial ownership has significant influence on audit quality of Nigerian quoted firms. The study recommended that, boards of corporate organisations in Nigeria should hearten greater participation of executive directors in taking up some of the shares of the companies they preside over in order to promote convergence of interest in achieving overall corporate objective.
\end{abstract}

Keywords: Audit Fees, Audit Size, Convergence of Interest, Corporate Governance, Managerial Ownership

\section{Introduction}

Ownership structure is a topical issue that has received comprehensive attention in the extant literature as a major mechanism of corporate governance that has the potential of mitigating management ownership conflicts, protection of stakeholder interests and also enhancing high quality audit. Thus, ownership structure is one of the primary corporate governance control mechanisms through which shareholders (owners) can reduce management excesses [1]. The demand for independent audit services has its root in the principalagent conflicts which have been a contending issue due to the separation of management from ownership. Corporate entities, most especially those listed on the stock exchanges are owned by a large number of disperse shareholders (owners) and the day to day administration of the firms is undertaken by management team that may not have substantial interests in the shares of the company [2]. This implies that the shareholders (owners) have residual claim over the resources of the firm and management only inform the shareholders about their stewardship of the entity's resources through the presentation of annual financial reports [3]. In order to certify that the annual financial reports so prepared by the management are credible and dependable for various stakeholders use, it is legally mandatory that such reports be subjected to external scrutiny by independent professional auditors. The presentation of an audit report that is of high quality therefore is perceived to enhance confidence in such report.

According to Al-Matari, Al-Matari and Saif [4], for their role in serving as an outside governance tool, the external auditors certify that the financial reports presented to the board and other stakeholders are credible. In addition, the external auditor facilitates the eradication of the likelihood of 
asymmetric information to happen between directors and other stakeholders and also alleviates the gap created as a result of separation of management from ownership [5]. Thus, ownership structure is one of the primary corporate governance control mechanisms through which shareholders (owners) can reduce management excesses [1]. Dominant shareholders, institutional shareholders and managerial shareholders are believed to have both the incentives and the ability to keep management in check. It is on the basis of the foregoing that this present study examined the impact of managerial ownership on the audit quality of quoted manufacturing companies in Nigeria.

\subsection{Statement of the Problem}

Globally, a number of researchers and experts from different fields such as finance, economics, auditing and accounting have shown considerable interests in audit quality during the past few decades. This aspect of accounting has become very essential as a result of the important role of an external auditor in contributing to the value and reliability of the financial statements prepared by the management [6]. However, the global financial crisis that have been reported in recent years has further stressed the need for a high quality audit as this is one of the main factors that affect the credibility of financial information and the higher the audit quality, the more the accuracy of the information in the financial statements. Hence, the auditors have been grossly relied upon as the external party who can form an unbiased judgment on the financial statements trueness and fairness. The establishment of an effective corporate governance system which can be fulfilled in the light of interaction between corporate governance external and internal control mechanisms will effectively bring about goal congruence between the interests of management and shareholders towards actualization of the overall corporate objective [5] and increase the organization's performance and growth [7]. Towards achieving this effective corporate governance objective, this present study examined the impact of an internal governance mechanism (insider/managerial ownership) on another external corporate governance mechanism (audit quality) of which literature review points to the fact that less attention has been given to this aspect. In achieving this objective, the following hypothesis was developed:

$\mathrm{H}_{0}$ 1: Managerial ownership has no significant impact on audit quality.

\subsection{Justification and Development of Hypothesis}

\section{Managerial Ownership Structure and Audit Quality}

According to Morck, Shleifer, and Vishny [8], managerial ownership reflects two agency problems between managers and shareholders. In the first instance, conflict-of-interests effect was established, in such a way that actual drives to act in the external shareholders' interest with less shareholding stakes was absent. Secondly, there is entrenchment effects in which directors with greater shareholding interests have higher influence over the firm hence, a superior opportunity for acting in their selfish interests. According to agency theory, the demand for increased audit quality is occasioned by the agency problems [9]. The managerial ownership structure was measured as the percentage of company's shares held by members of the board over the firm's entire ordinary share. This is in line with what obtains in the literature [10]. This ownership structure is perceived to have an important role as a tool of internal corporate governance.

The study conducted by Jensen and Meckling [11], established that the metric might play a potential role of motivation to engender management-shareholders goal congruence. Managerial ownership can alleviate agency conflicts between owners and management because, ownership of a significant percentage of the company's shares by the managers may motivate the board to optimize the general wellbeing of the entity of which audit quality is one [4]. However, Khan, Nemati and Iftikhar, [12], posited that increased ownership by the management was believed to cause management entrenchment since the board of directors did not have complete control over them. It is expected in this study that an effective control exercised by managerial ownership structure should bring about lower levels of audit failure. We therefore hypothesize that:

$\mathrm{H}_{0} 1$ : Managerial ownership structure does not have significant impact on audit quality of quoted manufacturing companies in Nigeria.

\section{Literature Review}

\subsection{Conceptual Framework}

\subsubsection{Managerial/Insider Ownership}

This is ownership structure whereby, the shareholders of the company are present on the board of directors and thus participate in the management of the company. According to Jensen and Meckling [10], the effect of managerial ownership on the value of firm is associated with the belief that such value hinges on the spreading of proprietorship between directors and other investors who have stake in the company. Within this discuss and the motivation debate, allotting firm's shares to directors motivates them to act like shareholders. In a rare occasion, a company with an owner who doubles as the manager is associated with reduction in agency costs [10]. Entrepreneurship theory additionally supports the notion that directors who also have block holdings will also consider new investment prospects, hence, entrepreneurship theory someway supports the incentive theory because, it offers a basis for the positive impact of the ownership by the management in the entity with comparatively diverse ownership structure. All the studies carried out so far on the significance of managerial ownership concluded that the best means to resolve the conflict between the manager and the shareholders is for the managers to acquire a substantial ownership interest in the corporate entity which they manage. If the manager's goals are in tandem with shareholders' objectives, the shareholders 
and managers' conflict could be settled with manager ownership stake in the firms.

\subsubsection{Audit Quality}

Basically, audits are necessary tool employed by management to evaluate how effective procedures have been applied for measuring the efficacy of actualizing any definite goal in providing evidence relating to decreasing and eradication of problem areas. The call for audit quality has been driven by the need to manage conflict of interest between agent and manager. Asymmetric information between shareholders and managers generates a moral risks problem. A distinction is drawn between sufficiency and appropriateness of audit evidence. Whereas the measure of the quality of audit evidence, that is, how many of audit evidence need to be gathered is regarded as sufficiency; appropriateness represents the degree of the quality of the audit evidence, that is, its reliability and relevance for detecting misrepresentations in the financial statements. When the auditor used the information provided by the firm to perform audit procedures, audit evidence about the accuracy and the completeness of the information should be obtained by the auditor [13]. Therefore, audit quality is defined as "a systematic, independent process of gathering objective evidence to determine whether audit criteria are being met. Audits are based on sample and independent of the system, process or product being audited, unlike verification activities which are part of a process [14]. A quality audit is an example of quality assurance while investigation and testing are examples of the quality control process.

\subsection{Theoretical Framework}

The Theory of Inspired Confidence (Theory of Rational Expectations)

The theory of inspired confidence discourses both the demand and the supply aspects of audit services. According to Limperg [15], the demand for audit services is as a result of the participation of third parties in the company. The relationship of accountability is realized through the presentation of periodical statements of accounts; conversely, as external stakeholders may not be able to monitor any substantial misinformation in the financial reports, the request for an autonomous and dependable outside audit is essential to ensure the dependability of the financial information. The external stakeholders call for stewardship rendition from the board, as a result of their investment in the firm. With regard to the supply of audit assurance, Limperg [15] suggests that the auditor should always strive to meet the public expectations. The provision of audit related services is expected to engender confidence caused by the auditing and satisfy public anticipations, as the overall responsibility of audit is consequent upon the reason for autonomous investigation and an independent opinion grounded on discoveries; owing to the assurance the public have in an independent auditors' opinion. It is therefore presumed that if the confidence the society repose in auditors' opinion is lost, the general significance of audit will be impaired; as audit conveys benefits to the financial statements users. Consequently, the auditor should uphold adequate business ethics to preserve his independence from the client firm being audited for the purpose of delivering his obligation to assess business practices and offer a credible and reliable opinion on the financial statements.

\subsection{Empirical Framework}

\section{Managerial Ownership Structure and Audit Quality}

The level of ownership by management in a firm may impact directors' motivations for the nature and value of financial information created which can reduce information asymmetry and impact on auditor's assessment of total audit risk for their client firms and choice of auditor. A myriad of empirical studies has been conducted on the relationship between ownership structure and audit quality with different results. Sulong, Gardner, Hussin and Mohd-Sanusi [16], examined the association between managerial ownership and quality of audit of firms quoted on the Malaysian Ace Market. The study used correlation analysis and multiple regressions to test the research hypotheses. The regression result indicates that the relationship between managerial ownership and audit fees is not statistically significant. Lin and Liu [17] studied the association between managerial ownership and audit fees of listed Hong Kong firms from 1999 to 2007. The result indicated a reverse association between management shareholding interest and fees paid for audit based on convergence of interest criterion, and a positive significant association between the constructs based on entrenchment criterion.

Similarly, Lennox [18] studied managerial ownership and audit size of large unlisted companies in the United Kingdom. The multivariate results showed that the relationship between managerial ownership and audit size was negative but significant within low and high boundaries of ownership by management. The relationship is flatter and slightly positive within intermediate regions of management ownership, indicating the possibility of an inverse entrenchment impact. Ownership structure and audit quality of Nigerian deposit money banks was studied by Ibn Adam et al. [19]. The paper primarily aimed at accessing the likely impact of managerial ownership and institutional ownership on audit quality of the Nigerian deposit money banks. In trying to achieve this, data was extracted from the sample of 10 banks out of the 24 population through banks annual reports and accounts for the periods 2007 to 2011 . The data was empirically tested using OLS regression. A positive and significant relationship was established between managerial shareholding and audit quality of the Nigerian Deposit Money Banks.

\section{Data and Methodology}

The main focus of this study is the examination of managerial ownership impact on audit quality of quoted manufacturing companies in Nigeria from 2007 to 2017. 


\subsection{Research Design}

Given the nature of this study, Experimental research design was adopted in achieving the objective.

\subsection{Population, Sample Size and Source of Data}

A population of 185 companies quoted on the Nigerian Stock Exchange (NSE) as at 31 December 2017 was used in this study. 36 manufacturing firms were selected as sample size using the non-probability (judgmental) sampling technique. Sequel to the thrust of this study, secondary data was employed. The data on managerial ownership and audit quality (audit fees and audit size) was extracted from the annual financial statements of all the sampled firms from 2007 to 2017.

\subsection{Variables Definition and Measurement}

For the purpose of this study, managerial ownership is the independent variable while audit quality is the dependent variable. Audit fees and audit firm size are the constructs for audit quality. Firm size (FSize) and financial leverage (FLev) were employed as control variables metrics.

Managerial ownership: Management ownership in this study was measured as the percentage of shares held by the directors in their respective firms. This is in line with the studies conducted by Al-Matari et al. [4]; Ibn Adam et al. [19] and Sulong et al. [16].

\section{Total number of shares owned by the directors

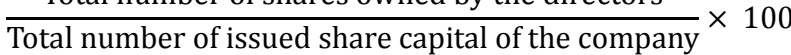

Audit Size: The size of the audit firm has been regarded by Chang, Gygax, Oon and Zhang [21] as the best commonly employed measure of audit quality as a result of the wide range of notional, academic and experimental proof that bigger auditors possibly will deliver greater audit quality. The bigger auditors take additional fee for their superior status and also their reputation. Additionally, their impressive clients' base, accords them the motivation to be more unbiased, which brings about a higher level of quality audit [22]. Audit quality was ascribed 1 when the firm is audited by one of the big 4 audit firms (Akintola Williams Delloite, Price WaterHouse Coopers, Ernst and Young, and KPMG) and zero otherwise [23].

Audit Fees: Audit quality can be assessed through audit fees [24]. The big audit firms are perceived to have higher audit quality and consequently, are probable to attract higher audit fees. Following the superior knowledge of the auditor, larger auditors may request an amount that is fairly greater than that of the small audit firms [24]. On the average, the premium of big auditors hovers around 20\% [25]. In this study, audit fee was measured by the natural log of audit fees to improve the linearity between audit fees and explanatory variables.

The control variables of firm size and financial leverage were used in controlling the effect of company peculiar financial factors, the choice of these two variables are in tandem with similar prior empirical studies [26, 27].

Firm Size: The effect of firm size in contributing to firm overall performance is assumed to be of two fold [28]. Firstly, bigger firms may have the potential of accessing funds easily. The second, instance is that large corporate entities may also be able to create entry barriers. The size of companies in this study was measured by the natural logarithm of total assets $[26,27]$ thus:

$$
\text { Fsize }_{\mathrm{i}, \mathrm{t}}=\mathrm{LN}(\mathrm{TAi}, \mathrm{t})
$$

Where: Fsize is Firm size; LN represents Natural logarithm and TA stands for Total Assets.

Financial Leverage: Angaye et al. [29] opined that debt owners may possess extra management controls on directors more than the shareholders. This may assuage conflicts of interest between stockholders and managers. Similarly, Banks loan to firms is construed to be a useful means for reducing the agency problem [28]. In this study, the percentage of total debts to total assets was used to measure leverage $[23,30,26,27]$.

$$
\frac{\text { Total Debts }}{\text { Total Assets }} \times 100
$$

\section{Data Analysis}

This study employed descriptive and inferential statistics. Panel data methodology was employed for estimation while multiple regressions were used for analysis.

\subsection{Model Specification}

The sole thrust of this study is to examine the impact of managerial ownership and surrogates of audit quality of manufacturing companies quoted on the Nigerian Stock Exchange. To achieve this objective, the following regression model of Zuregat [27] was adapted.

$$
\mathrm{AQ}=\alpha+\beta_{1} \mathrm{OC}+\beta_{2} \mathrm{FO}+\beta_{3} \mathrm{IO}+\beta_{4} \mathrm{SI}+\beta_{5} \mathrm{LE}+e
$$

Where: AQ is audit quality; OC represents ownership; FO represents foreign ownership; IO is institutional ownership; SI represents company size; and LE means leverage.

Implicit Model

The following model was formulated for the purpose of this study

$$
\mathrm{AQ}_{\mathrm{it}}=\alpha_{\mathrm{it}}+\beta_{1} \mathrm{M}-\mathrm{own}_{\mathrm{it}}+\beta_{2} \text { Fsize }_{\mathrm{it}}+\beta_{3} \text { Flev }_{\text {it }}+e_{\mathrm{it}}
$$

Explicit Model

$$
\begin{aligned}
& \operatorname{AUDif}_{\text {it }}=\alpha_{\text {it }}+\beta_{1} \mathrm{M}-\mathrm{own}_{\mathrm{it}}+\beta_{2} \text { Fsize }_{\mathrm{it}}+\beta_{3} \mathrm{Flev}_{\mathrm{it}}+e_{\mathrm{it}} \\
& \text { AUDis }_{\text {it }}=\alpha_{\text {it }}+\beta_{1} \text { M-own }_{\text {it }}+\beta_{2} \text { Fsize }_{\text {it }}+\beta_{3} \text { Flev }_{\text {it }}+e_{\text {it }}
\end{aligned}
$$

Where; AQ represents audit quality (dependent variable) measured as audit fees (AUDif) and audit size (AUDis) while the explanatory variables are managerial ownership (Mown); Firm size (Fsize) and Financial leverage (Flev). The alpha $(\alpha)$ and batas $(\beta)$ are the regression coefficient and the 
subscript $\mathrm{i}$ and $\mathrm{t}$ signify the quoted firms (i) at time $(\mathrm{t}) ; \mathrm{t}=$ $2007 \ldots . . .2017$.

\subsection{Results and Discussions of Findings}

\subsubsection{Descriptive Statistics}

The result in Table 1 presents the number of observations, mean, median, maximum, minimum and standard deviation of each of the dependent and independent variables. The table shows two categories of variables. The first category is the dependent variables which are the audit fees (Audif) and audit size (Audis). The second category is the explanatory variables which include managerial ownership (M-own), firm size (F-size) and financial leverage (F-lev).

Audit Fees (Audif)

From Table 1, audit fees takes values between N450.00 and N1,293,405.00 with a Standard deviation of 67,119.17. These show that the fees paid to the external auditors by each of the selected firms and over the period of 11 years (20072017) considerably varied. Besides, the average values for all the firms is N18,556.08. This average figure is considerably greater than the median figure of N9,337.50. This further confirmed that the fees paid to the external auditors by each of the selected firms and over the period of 11 years (20072017) considerably varied and on average, the firms paid $\mathrm{N} 18,556.08$.

Audit Size (Audis)

Audit size as presented in Table 1 has a minimum value of 0 and a maximum value of 1 . These figures depict that the indicator is truly a dummy variables with the value of one (1) where the service of external auditor engaged by any of the firms in any of the years under study is one of the BIG4 and zero (0) otherwise. Additionally, the average value of Audit Size is 0.63 suggesting that the services of the BIG4 audit firms engaged during the study period was about $63.0 \%$.

\section{Managerial Ownership (M-own)}

Managerial ownership in Table 1 has a minimum value of 0 and a maximum value of 0.72 with a Standard deviation of 0.16 . In addition, the average value for all the firms is 0.10 ; this figure is noticeably greater than the median figure of 0.01 . On the average, ownership by the management of the sampled firms during the study period (2007-2017) is about $10 \%$.

Table 1. Summary Statistics.

\begin{tabular}{llllll}
\hline & Obsns & Mean & Median & Maximum & Minimum \\
\hline Dependent Variable & & & & & \\
AUDif & 396 & $18,556.08$ & $9,337.50$ & $1,293,405.00$ & 450.00 \\
AUDis & 396 & 0.63 & 1.00 & 1.00 & 0.00 \\
Independent Variable & & & & \\
M-own & 396 & 0.10 & 0.01 & 0.72 & 0.00 \\
F-size & 396 & 15.81 & 15.77 & 20.10 & 0.119 \\
Flev & 396 & 1.01 & 0.56 & 22.06 & 0.17 \\
\hline
\end{tabular}

Source: Author's desk report (2019), Note: Audit Fees (Audif), Audit Size (Audis), Managerial ownership (M-own), Firm Size (Fsize) and Financial leverage (Flev).

\subsubsection{Correlation Analysis}

In this segment, we present the result of correlation analysis that shows the degree of correlations among the selected variables in this study as part of the preliminary analysis. The results of the correlation which considers audit fees (Audif), audit size (Audis), managerial ownership (Mown), with firm size (Fsize) and financial leverage (Flev) are discussed. This result is to establish if there are bivariate correlations between each pair of the explained and explanatory variables considered in the subsequent analysis and to confirm that the correlations among the explanatory variables are not so high to the extent of posing multicollinearity problems. According to the result in Table 2, there are existence of positive correlations between audit size
(Audis), firm size (Fsize) and audit fees (Audif) with the correlation coefficients $\mathrm{r}=0.673$ and $\mathrm{r}=0.845$ respectively.

However there were existence of negative correlations between managerial ownership (M-own), financial leverage (Flev) and audit fees (Audif) with the correlation coefficients $r=-0.465$ and $r=-0.181$ respectively. Focusing on the correlation between audit size (Audis) and the rest of the variables, the correlation coefficient of $r=0.521$, indicates that firm size (Fsize) maintained positive association with audit size (Audis) while managerial ownership (M-own), financial leverage (Flev) maintained negative associations with audit size (Audis) with the correlations coefficients of $r$ $=-0.358$ and $\mathrm{r}=-0.201$.

Table 2. Correlation Matrix

\begin{tabular}{|c|c|c|c|c|c|}
\hline Correlation & AUDif & AUDis & M-own & F-size & Flev \\
\hline AUDit & 1 & & & & \\
\hline AUDis & 0.673 & 1 & & & \\
\hline M-own & -0.465 & -0.358 & 1 & & \\
\hline F-size & 0.845 & 0.521 & -0.136 & 1 & \\
\hline Flev & -0.181 & -0.201 & -0.096 & -0.333 & 1 \\
\hline
\end{tabular}

Source: Author's desk report (2019), Note: Audit Fees (Audif), Audit Size (Audis), Managerial ownership (M-own); and control variables are Firm size (Fsize) and Financial leverage (Flev). 


\subsubsection{Regression Analysis}

Model 1: Managerial Ownership and Audit Fees (AUDif)

$$
\begin{gathered}
\text { AUDif }_{\text {it }}=0.604-0.2410 \mathrm{M}-\mathrm{own}_{\mathrm{it}}-0.525 \mathrm{Fsize}_{\mathrm{it}}+ \\
0.029 \mathrm{Flev}_{\mathrm{it}}+e_{\mathrm{it}}
\end{gathered}
$$

This section contains random and fixed effects regression models which were employed in assessing the impact of managerial ownership on audit quality of Nigerian quoted manufacturing companies. In deciding between random effect model and pooled (OLS), the Breusch and Pagan Lagrangian multiplier test was used. However, to choose between pooled and random effect models Hausman specification test was employed. From the result in Table 3, the $\mathrm{P}$-value (0.644) is statistically insignificant, hence, the null hypothesis was accepted which concluded that the random effect model is considered appropriate to establish the impact of managerial ownership on audit quality of manufacturing companies in terms of audit fees (Audif).

Table 3. Lagrange Multiplier and Hausman Test for Audit Fees.

\begin{tabular}{lll}
\hline Tests & Breusch-Pagan Lagrange Multiplier (LM) & Hausman test \\
\hline Chi2 & 703.95 & 4.241 \\
P-Value & 0.000 & 0.644 \\
\hline
\end{tabular}

Source: Author's desk report (2019).

\section{Discussion of Findings}

The random effect model is favoured in Table 4 which shows that random effect is statistically significant $(\mathrm{F}=$ 52.557; $\mathrm{P}$ - value $=0.000)$. The R-squared $\left(\mathrm{R}^{2}\right)$ value of
0.448 shows that the explanatory variables explain $44.80 \%$ variations that occur in audit fees (AUDif). The coefficient of -0.241 in relation to managerial ownership suggests that there is a negative and insignificant impact of managerial ownership on audit fees (AUDif) given the p- value of 0.287. Furthermore, it explains that a unit increase in managerial ownership will attract about 0.241 unit decline in audit fees (AUDif). The finding of this study is in tandem with the result of the study carried out by Lin and Liu [17]. Their result indicated an inverse association between management shareholding interest and audit fees in Hong Kong. Similarly, Sulong, et al. [16] found no statistically significant relationship between managerial ownership and audit fees in Malaysia. However, in contrast to the result obtained from this study, Ibn Adam et al. [19] documented a positive and significant relationship between managerial shareholding and audit quality of the Nigerian Deposit Money Banks.

For Firm size (Fsize), a significant coefficient has been confirmed at the level of significance of $P=0.000$. This connotes that one unit increase in firm size (Fsize) will lead to 0.525 units increase in audit quality of the selected firms in Nigeria. Hence, the level of significance suggests that the effect of firm size (Fsize) on audit fees (AUDit) of the selected firms in Nigeria is significant. Examining the financial leverage (Flev) coefficient (0.029), the findings indicate that financial leverage (Flev) has a significantly positive impact on audit fees $(\mathrm{p}=0.001)$, hence, the significant result means that a unit increase in financial leverage (Flev) will attract an increase of 0.029 in audit fees (Audif).

Table 4. Regression result of Audit Fees.

\begin{tabular}{llll}
\hline VARIABLES & POOLED EFFECT & RAMDOM EFFECT & FIXED EFFECT \\
\hline & -0.358 & -0.241 & -0.158 \\
M_OWN & $(0.232)$ & $(0.226)$ & $(0.210)$ \\
& {$[0.124]$} & {$[0.287]$} & {$[0.452]$} \\
& $0.490^{* * *}$ & $0.525^{* * *}$ & $0.553^{* * *}$ \\
F_SIZE & $(0.014)$ & $(0.041)$ & $(0.053)$ \\
& {$[0.000]$} & {$[0.000]$} & {$[0.000]$} \\
& $0.035^{* * *}$ & $0.029^{* * *}$ & $0.029^{* * *}$ \\
FLEV & $(0.008)$ & $(0.009)$ & $(0.010)$ \\
& {$[0.000]$} & {$[0.001]$} & {$[0.002]$} \\
C & $1.326^{* * *}$ & 0.604 & 0.207 \\
& $(0.274)$ & $(0.683)$ & $(0.771)$ \\
Observations & {$[0.000]$} & {$[0.377]$} & {$[0.788]$} \\
$R^{2}$ & 396 & 396 & 396 \\
Adj. $R^{2}$ & 0.747 & 0.448 & 0.911 \\
F-Statistic & 0.743 & 0.439 & 0.901 \\
Prob. (F-Stat.) & 191.525 & 52.557 & 88.503 \\
\hline
\end{tabular}

Source: Author's Field Report, (2019), Note: The dependent variable is Audit Fees (Audif). The explanatory variables are Managerial ownership (M-own); Firm size (Fsize) and Financial leverage (Flev); Standard deviation ( ), Probability [ ]. ${ }^{* *} \mathrm{p}<0.01,{ }^{* *} \mathrm{p}<0.05,{ }^{*} \mathrm{p}<0.1$.

\subsubsection{Audit Fees Diagnostic Tests Results}

Jarque-Bera statistics was used to check whether the error term of the model estimated with Audit fees being regressed on managerial ownership and control variables of firm size and financial leverage is normally distributed. Figure 1 shows that the test statistics and the related p-value is statistically insignificant. These suggest that the residual is normally distributed. Heteroskedasticity standard error was used in testing for heteroskedasticity, therefore, the test for constant variance was required. 

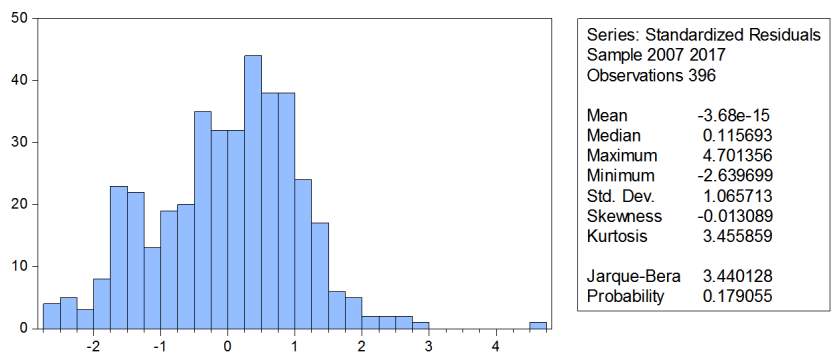

Figure 1. Audit Fees Diagnostic Tests.

\section{Model 2: Managerial Ownership and Audit Size (AUDis)}

AUDis $_{\text {it }}=0.825-0.562 \mathrm{M}-\mathrm{own}_{\mathrm{it}}+0.012 \mathrm{Fsize}_{\mathrm{it}}-0.003 \mathrm{Flev}_{\mathrm{it}}$ $+e_{\mathrm{it}}$

This subsection presents impact of managerial ownership on audit size (AUDis) of Nigerian quoted manufacturing companies using the pooled (OLS), random effect and fixed effect models. Here, Audit Size (Audis) is dependent variable while managerial ownership, firm size (Fsize) and financial leverage (Flev) represent the explanatory variables. Considering the Breusch and Pagan Lagrange multiplier (LM) in Table 5, the significant p-value (0.000) of the test implies that random effect model is preferred over Pooled. Knowing that the pooled regression isn't favoured, the study conducted Hausman test to choose between Random effect model and fixed effect model. From the result in Table 5, the $\mathrm{P}-$ value (0.022) is statistically significant. Therefore, the null hypothesis is rejected and concludes that the fixed-effects estimator is more efficient in this case. Hence, fixed effect model results in Table 6 are interpreted for the purpose of this study.

Table 5. Breusch and Pagan Lagrange multiplier and Hausman Tests.

\begin{tabular}{lll}
\hline Tests & $\begin{array}{l}\text { Breusch-Pagan Lagrange } \\
\text { Multiplier (LM) }\end{array}$ & Hausman test \\
\hline Chi2 & 606.74 & 14.81 \\
P-Value & 0.000 & 0.022 \\
\hline
\end{tabular}

Source: Author's desk report (2019).

\section{Discussion of Findings}

The fixed effects column as shown in Table 6 shows a significant $\mathrm{F}$-statistics value $(25.769 ; \mathrm{P}$ - value $=0.000)$. The $\mathrm{R}^{2}$ value of 0.749 means that the explanatory variables account for $74.90 \%$ variations in the dependent variable. The coefficient $(\beta=-0.562$; $\mathrm{p}$ - value $=0.002)$ of managerial Ownership (M-Own) with emphasis on audit size is significant $(\mathrm{P}<0.01)$. The result shows that managerial ownership has a negative but significant impact on audit quality. The finding of this study aligns with the finding of Lin and Liu [17] who documented a positive significant association between management ownership and audit quality based on entrenchment criterion. Also, Lenox [18], found a significant but negative relationship between management ownership and audit firm size in the United Kingdom. Considering firm size (Fsize), the coefficient is positive but insignificant $(\beta=0.012$; $p$-value $=0.581)$. For the coefficient of financial leverage (Flev), the results show a negative and significant impact of financial leverage (Flev) on audit size $(\beta=-0.003$; $p$-value $=0.584)$.

Table 6. Regression result of Audit Size.

\begin{tabular}{|c|c|c|c|}
\hline VARIABLES & POOLED EFFECT & RAMDOM EFFECT & FIXED EFFECT \\
\hline \multirow{3}{*}{$M-O W N$} & $-0.533 * * *$ & $-0.529 * * *$ & $-0.562 * * *$ \\
\hline & $(0.181)$ & $(0.187)$ & $(0.181)$ \\
\hline & {$[0.004]$} & {$[0.005]$} & {$[0.002]$} \\
\hline \multirow{3}{*}{$F-S I Z E$} & $0.107 * * *$ & $0.059 * * *$ & 0.012 \\
\hline & $(0.007)$ & $(0.017)$ & $(0.022)$ \\
\hline & {$[0.000]$} & {$[0.001]$} & {$[0.581]$} \\
\hline \multirow[t]{2}{*}{$F L E V$} & $(0.005)$ & $(0.005)$ & $(0.005)$ \\
\hline & {$[0.004]$} & {$[0.710]$} & {$[0.584]$} \\
\hline \multirow{3}{*}{ C } & $-0.865^{* * *}$ & 0.073 & $0.825 * * *$ \\
\hline & $(0.120)$ & $(0.267)$ & $(0.296)$ \\
\hline & {$[0.000]$} & {$[0.786]$} & {$[0.005]$} \\
\hline Observations & 396 & 396 & 396 \\
\hline$R^{2}$ & 0.312 & 0.126 & 0.749 \\
\hline F-Statistic & 29.442 & 9.362 & 25.769 \\
\hline Prob. (F-Stat.) & 0.000 & 0.000 & 0.000 \\
\hline
\end{tabular}

Source: Author's Field Report, (2019), Note: The dependent variable is Audit Fees (Audif). The explanatory variables are Managerial ownership (M-own); Firm size (Fsize) and Financial leverage (Flev); Standard deviation ( ), Probability [ ]. *** p $<0.01, * * \mathrm{p}<0.05, * \mathrm{p}<0.1$.

\subsubsection{Audit Size Diagnostic Tests}

Jarque-Bera statistics was employed to check whether the error term of the estimated model when the Audit Size is regressed on explanatory variables is normally distributed. From Figure 2, the test statistics and its associated p-value is statistically insignificant. These mean that the residual is normally distributed. For heteroskedasticity, the study used heteroskedasticity consisted standard error, hence the test for constant variance isn't required. 


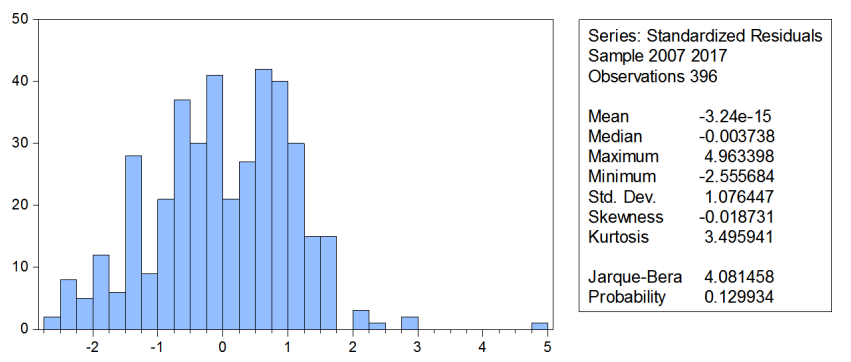

Figure 2. Diagnostic Tests for Audit Size.

\section{Conclusion}

This study examined the impact of managerial ownership on audit quality of Nigerian quoted manufacturing companies from 2007 to 2017 using descriptive, correlational and experimental analysis. It was found that managerial ownership does not have a positive and significant impact on audit fees $(\beta=-0.241 ; \mathrm{p}=0.287)$ while managerial ownership has a negative but significant impact on audit size $(\beta=-0.562 ; \mathrm{p}$ - value $=0.002)$. Based on the findings of this study and the theory upon which the study is anchored, it can be inferred that managerial ownership does not have a positive and significant impact on audit fees while managerial ownership has a negative but significant impact on audit size. The study therefore concluded that managerial ownership has a significant impact on audit quality.

\section{Recommendations}

Sequel to the findings in this study, it is recommended that, corporate organization decision makers should place greater emphasis on the facilitation of equity capital as an alternative to external debt, since it provides a base for further borrowing and reduces business sensitivity to hostile takeover. Furthermore, management of corporate organisations in Nigeria should encourage greater participation of executive directors in taking up some of the shares of the companies they preside over. According to entrenchment hypothesis proponents, the more attached the directors are to their respective organisations the more committed they become and the less the monitoring cost; which eventually contributes to the general wellbeing of the firms. This study is one of the few studies in Nigeria that examined the relationship between ownership structure and audit quality as a further contribution to the ongoing debate on the examination of internal and external corporate governance mechanisms.

\section{References}

[1] Elston, J., Hofler, R., \& Lee. J. (2011). Dividend policy and institutional ownership: Empirical evidence using a propensity score matching estimator. Journal of Accounting and Finance, $11(1), 89-102$.

[2] Enofe, A., Mgbame, C., Aderin, A., Ehi-Oshio, O. (2013),
Determinants of audit quality in the Nigerian business environment. Research Journal of Finance and Accounting, 4 (4), 36-43.

[3] Security and Exchange Commission (2000), Code of corporate governance in Nigeria.

[4] Al-Matari, E. M., Al-Matari, Y. A. \& Saif, S. A. (2017). Ownership structure, audit quality and firm performance moderating and direct-effect models: An empirical study, Corporate Board: Role, Duties and Composition, 13 (1), 2835 .

[5] Fama, E. F, \& Jensen, M. C, (1983). Separation of ownership and control, Journal of Law and Economics, 26 (2). 327-349.

[6] Al-Rawash, K. A. \& Alzeaideen, S. Z. (2018). The effect of ownership structure and corporate debt on audit quality: Evidence from Jordan, International Journal of Economics and Financial Issues, 8 (3), 51-58.

[7] Seyedeh, E. M. R., Hamid S., \& Hashem, V. P. (2016). The impact of audit quality and ownership structure on earnings management on Tehran Stock Exchange. International Business Management, 10 (10), 1827-1832.

[8] Morck, R., Shleifer, A. \& Vishny. R. W. (1988). Management ownership and market valuation: An empirical analysis. Journal of Financial Economics, 20 (1), 292-315.

[9] Watts, R. L., \& Zimmerman, J. L. (1990). Positive accounting theory: A ten year perspective. The Accounting Review, 65 (1), 131-156.

[10] Wahla, K. U. R., Shah, S. Z. A., \& Hussain, Z. (2012). Impact of ownership structure on firm performance evidence from non-financial listed companies at Karachi stock exchange. International Research Journal of Finance and Economics, (84), 6-13.

[11] Jensen, M. C. \& Meckling, W. H. (1976). Theory of the firm: Managerial behaviour agency costs and ownership structure. Journal of Financial Economics. 3 (4), 305-360.

[12] Khan, K., Nemati, A. R., \& Iftikhar, M. (2011). Impact of corporate governance on firm performance evidence from the tobacco industry of Pakistan. International Research Journal of Finance and Economics, 61, 7-14. 31.

[13] Soyemi, K. (2014). Auditing and assurance services. Abeokuta, Leksilicon Publishing Company Limited.

[14] Vroeijenstijn, A. I. (1995). Improvement and Accountability: Navigating between Scylla and Charybdis, Guide for External Quality Assessment in Higher Education, Jessica Kingsley Publishers, London.

[15] Limperg, T. (1932). Theory of inspired confidence. University of Amsterdam, Netherlands. 26.

[16] Sulong, Z., Gardner, J. C., Hussin, A. H., Mohd-Sanusi, Z., \& McGowan, C. B. (2013). Managerial ownership, leverage and audit quality impact on firm performance: Evidence from the Malaysian Ace Market. Accounting and Taxation, 5 (1). 59-70.

[17] Lin, Z. J. \& Liu, M. (2013). The effect of managerial shareholding on audit fees: Evidence from Hong Kong. International Journal of Auditing, 17 (3), 227-245.

[18] Lennox, C. (2005). Management ownership and audit firm size. Contemporary Accounting Research, 22 (1), 206-227. 
[19] Ibn Adam, S. \& Bala, H. (2015). Ownership structure and audit quality of Nigerian deposit money banks. Journal of Social Sciences and Management Science 2 (3), 54-65.

[20] Chang, X., Gygax, A. F., Oon, E. \& Zhang, F. (2008). Audit quality, auditor compensation and initial public offering underpricing, Accounting and Finance, 48 (3), 391-416.

[21] De-Angelo, L. E. (1981). Auditor independence, low balling and disclosure regulation. Journal of Accounting and Economics, 3, 183-199.

[22] Abdullah, W. Z. W. (2008). The impact of board composition, ownership and CEO duality on audit quality: The Malaysian evidence, Malaysian Accounting Review, 7 (2), 17-28.

[23] Simunic, D. (1980). The pricing of audit services: Theory and evidence. J. Account. Res., 18, 161-190.

[24] Francis, J. (2004). What do we know about audit quality? Br. Account. Rev., 34, 345-368.
[25] Kheirollahi, F., Behshour, I., \& Azadi, M. (2014). Investigating the effect of corporate governance mechanisms (company ownership structure) on audit quality. Indian Journal of Science Research, 4 (3), 465-469.

[26] Zureigat Q. (2011). The effect of ownership structure on audit quality: Evidence from Jordan, International Journal of Business Social Science, 2 (10), 38-46.

[27] Boubakri, N., Cosset, J. C \& Guedhami, O. (2005). Post privatization corporate governance: The role of ownership structure and investor protection, Journal of Financial Economics 76 (2).

[28] Angaye, E. G., Gwilliam, D., Marnet, O. \& Thomas, D. (2000). Board structure and value added performance in Nigeria, Economics, finance and accounting applied research working paper series.

[29] Kane, G. D., \& Velury, U. (2004). The role of institutional ownership in the market for auditing services: An empirical investigation, Journal of Business Research, 57 (9), 976-983. 